\title{
The Early Childhood Curriculum Analysis Lecturing Strategy to Increase Pedagogical Competence in Mastering Concepts and the Ability to Develop Early Childhood Curriculum
}

\author{
I Nyoman Suarta ${ }^{1}$, Dwi Istati Rahayu ${ }^{2}$, Baik Nilawati Astini ${ }^{3}$, and I Made Suwasa \\ Astawa $^{4}$
}

${ }^{1}$ Early Childhood Department, University of Mataram, Mataram, Indonesia, suarta9@gmail.com

${ }^{2}$ Early Childhood Department, University of Mataram, Mataram, Indonesia, dwiistati@ unram.ac.id

${ }^{3}$ Early Childhood Department, University of Mataram, Mataram, Indonesia, nilaastini@ymail.com

${ }^{4}$ Early Childhood Department, University of Mataram, Mataram, Indonesia, astawa.fkip@ gmail.com

\begin{abstract}
This research was conducted for the students after attending a lecture mastery of curriculum study is still weak in relation to the concept of curriculum and development and the lack of a systematic and standardized guidelines for the study of curriculum subjects. This research aims to study the course curriculum drafting strategies to increase student pedagogic competence of ECD major at FKIP Mataram University in the mastery of the concepts and capabilities of early childhood curriculum development unit. This research is action that develop a learning system with lesson study model of Lewis (2002), implementation is done in three stages: (a) plan (plan), (b) implementation and obsrvasi (do), (c) the reflection (see). The research data were collected by the method of testing and assessment work in the form of documents. Data were analyzed using descriptive analysis. Based on the results of the data analysis of test results and assessment work in the form of document level curriculum for early childhood education, it is obtained conclusion that lectures strategies that can improve the mastery of concepts and increase the ability of the student curriculum development is the mastery of curriculum materials group through carried stages; (1) examines theories about curriculum with discussion method, (2) field studies, (3) discussion of the results of the field study and compared with theoretical concepts, (4) to draw conclusions about the concept of the curriculum.
\end{abstract}

Keywords - Strategies Lectures, courses Assessing ECD Curriculum

\section{INTRODUCTION}

Early childhood education is the foundation for further children's education, because it is the basis of the potential formation by stimulating the development of the child inborn. Law No. 20 of 2003 on National Education System mandates early childhood education should be designed and prepared well in order to do optimal stimulation. One thing that must be prepared is educators or teachers, as educators are one of the components that determine the quality of education.

Early childhood educator professional educators say when educators / early childhood teachers have pedagogic competence, personality, social and professional. One of the efforts to establish the pedagogic competence for teachers of early childhood education is through intensive coaching on Assessing curriculum subjects. In this course the students are equipped with concepts and theories about curriculum, conduct field studies related to early childhood curriculum and develop a curriculum in accordance with the criteria and requirements of early childhood education curriculum.

The fact is that students will take courses in the Curriculum the study still has some flaws that need to be addressed and improved. Weakness in question include in the mastery of the concept of curriculum, studying curriculum applied in the field with the concepts and criteria of the standard curriculum, the ability to develop and develop curricula in accordance with the criteria and standards of good curriculum. This condition occurs because the learning in the form of discussion and assignments that have not been accompanied by stages and standards, so that the course cannot be done in a systematic and measurable.

Patterns and reference systematic lectures neighbor assessing curriculum needs to be developed through research lesson or lesson study. Through lesson study will 
be conducted three stages starting from design, implementation and assessment. The third step is conducted in collaboration with a team of faculty and students who took a course study curriculum.

The draft strategy or lecture stages tested (implemented) and evaluated in order to obtain an effective strategy and stages of development of pedagogic competence of students. Educators will be able to develop the child's potential to the optimum when four competence or capability, namely: (1) have the knowledge, understanding of child development as the indicators of development; (2) to prepare and develop curriculum units and develop a learning plan that takes into account the elements supporting the learning process refers to a unitbased curriculum; (3) implementing the learning in accordance with the principles of early childhood education; (4) control and can carry out the assessment and process assessment child developments. Fourth this capability is absolutely necessary and is owned early childhood educators, that education conducted in early childhood is the process of stimulation of child development, learning materials not teaching activities.

In line with these conditions, based on experience as an assessor early childhood researchers foundd that understanding and ability early childhood teachers on a very limited curriculum, teachers still have trouble doing curriculum development, and any change curriculum so teachers will become confused what to do. The education process has been running but the reference curriculum is not arranged in a systematic unit, and it is thought that chewing on early childhood education as a curriculum. Faced with this condition candidate early childhood educators who will plunge into early childhood education should be prepared well in order to have an understanding,

The curriculum is an educational tool that should be owned by every academic year because the curriculum is a reference in education. Curriculum education unit was conceived and developed by educators together with the manager of the unit, so any policy changes related to the curriculum, the education unit shall adopt and develop curriculum unit. The curriculum units, especially in early childhood education is expected to have local peculiarities and national curriculum load. Therefore, an understanding of the curriculum, abilities and skills in curriculum development is needed by early childhood educators or teachers. Students PG-ECD as an early childhood educator candidate should have an understanding and ability to develop curriculum, so that when a teacher can carry out the obligations in accordance with the expected competencies. To build and develop student competency in relation to early childhood curriculum development unit, then coaching is done through the study of curriculum subjects should be carried out systematically and measurable. This research was conducted to develop strategies and efforts to be made to the systematic, consistent and scalable to develop pedagogical competence more candidates are expected.

\section{RESEARCH METHODS}

This research is action that develops learning system with lesson study model of Lewis (2002); implementation is done in three stages: (a) plan (plan), (b) implementation and observation (do), (c) the reflection (see). The subject matter of the study curriculum subjects were divided into 3 major groups namely the development of the concept of curriculum, assessment / review of curriculum and curriculum development in early childhood unit. This study conducted a study to develop a model or strategy classes to build pedagogic competence mastery of the curriculum students, especially aspects that have a readiness as early childhood teachers are competent.

The research will be conducted on students of fourth semester study program PGPAUD FKIP Mataram year university lectures. The subjects of this study were students of fourth semester study program PGPAUD FKIP Mataram University second semester of the academic year 2018/2019.

This study used a qualitative approach to data collection methods in the form of tests and assessment work in the form of units of early childhood curriculum documents. The research data is data description of the lecture and the ability of students achieved mastery of the material in the form of scores. These research data will be analyzed using descriptive analysis qualitatively.

\section{RESULTS AND DISCUSSION}

Application of the lectures strategy can improve their understanding of curriculum concepts and can develop into early childhood curriculum units where they perform field studies and provide input for curriculum development in the respective units. Stages lectures strategy study curriculum for each group of materials described in the following discussion.

1. Concept Mastery curriculum materials group.

a. In the group of materials about the concept curriculum lectures strategy pursued in phases:

1) Examine curriculum theory by the method of discussion.

After contracting lectures, study curriculum concept was preceded by a brief explanation of the meaning of curriculum, comparing some of the concepts of curriculum experts and discusses to gain an understanding of the concept curriculum based on theory.

2) study Courses

Once students understand the concept of a curriculum based on the theory, then the student is given the task to conduct the election unit Institute / early childhood as a place to conduct a study on the curriculum units through interviews and observations. In the process of studying the curriculum units that were targeted, students explore the concept of the curriculum in accordance with the understanding of teachers in a unit concerned. Activity field study ended with 
an agreement between students and administrators to restore the review of the curriculum is done in the classroom as a result of a review of the curriculum that are ready to be applied by managers and educators on the target unit.

3) Discussion of the results of the field study The results of the field study or understanding of the concepts acquired in the next field were presented and discussed in the lecture hall. Discussions are directed to a comparison between the concept-based curriculum theory and curriculum concepts acquired in the field. The process of comparing the aim to obtain a sample and the real conditions of theoretical concepts. Through the knowledge acquired from different sources students are expected to more accurately understand the concept of curriculum units of early childhood education.

4) Draw conclusions about the concept of curriculum

Based on the discussions about the concept of the next curriculum students draw conclusions about curriculum concepts related to the understanding, principles of curriculum development, the type and shape of the curriculum, the benefits of curriculum development and curriculum development in education.

2. Group study curriculum materials.

Strategy group discussion about the study curriculum materials carried out in four phases of activity as follows:

a. Discussions on the structure of early childhood curriculum

At this stage, students are invited discussion of the structure of the curriculum that applies to the application of K13 early childhood curriculum. This discussion is intended to make students gain an understanding and mastering standard curriculum structure ECD unit. The scope of materials that can be studied is srruktur curriculum consists of six chapters, the content and the discussion of each chapter.

b. Examining the early childhood curriculum unit Examining the early childhood curriculum unit performed on each chapter. Students examine the accuracy and disadvantages of each structure obtained in the unit of early childhood curriculum and the things that have not been included in the curriculum unit on each chapter has been conceived students. Also found many units incomplete curriculum structure, so the need to include and define the part structure of the curriculum that has not been contained.

c. Determine the form and content of the curriculum structure of the ECD unit
Based on the results of further study early childhood curriculum unit students make notes to determine the form and content of the discussion that should be present and included in the curriculum unit. In determining the content and discussion, the students need to find information related to early childhood education units with the vision and mission of the unit and local knowledge who want to develop a unit designed ECD.

\section{d. designing repair}

The information and data acquired to be used for drafting improvement to be repaired.

3. Material group ECD curriculum development unit Reconstruction activities in the early childhood curriculum units of each group of students carried out in stages starting from the identity of the level curriculum for education until the student back to the ECD unit to disseminate the results of the revision and or reconstruction has been done. Stages of activity for these materials are as follows:

a. Review the results of the study of the two materials.

Before starting the repair or revision of the curriculum gradually or section by section, do rereview of the improvement plan will be done. This is done by each group of students to an education unit level curriculum. Once considered a mature and there is no information and data required in the ECD unit is ready to revise or curriculum development unit.

b. Make improvements to each chapter of the curriculum

The curriculum revision is done every part of the curriculum unit in which the structure of the curriculum comprises six chapters and sections identity. Repair or revision of the curriculum starting from the curriculum as a cover identity, attestation, preface, table of contents and a list of attachments. Improvements made to the student groups each unit ECD curriculum conducted in the lecture hall during the hours of lectures, process improvement and accompanied by the preparation by the lecturer of the course. Mentoring aims to provide input and hooked up with a revised description and a description of the parts repaired or expanded.

c. Present and discuss the results of repair.

Results of development that is passed each chapter, then presented to gather feedback and build a common understanding in relation to the contents and description as well as the purpose or function of any part of early childhood curriculum unit. This stage is to strengthen and expand student understanding in relation to the implementation of the curriculum at every Education unit.

d. Improvements based on feedback

Based on the input and discussion of results of improvements that have been presented, then each 
group returned to the improvement or development in the next section.

e. Continuing improvements to the next chapter until selasai

Improvement of each part of the curriculum is done in stages, and the results presented to the class refinement, refinement in every part until the repairs are completed for all parts of the curriculum structure.

f. Presenting the results of the overall preparation Finished composing all part of the early childhood curriculum structure units, each group presented the results of the preparation and development carried out. At this stage done the overall review. Review is intended to look at the linkages and constitency between one part and another. When there are not consistent, then the final consummation of the outcome of the preparation and early childhood curriculum development unit.

g. Socialization of the units of early childhood curriculum improvement

The results of the reconstruction and development of a curriculum unit and then delivered or disseminated to the unit where the group of students made a deal to do Review curriculum. At this stage of development results also socialize student mastery of concepts and capabilities strengthen the curriculum development unit early childhood education.

Implementation phases of the course study the curriculum impact on improving the ability of students in mastering the concept of curriculum, study of the components of the curriculum and increase the ability of preparing and developing the level curriculum Education Early Childhood Education (SBC ECD), which is visible from the achievements of the results of tests on the concepts and mastery the three groups of subjects The study curriculum materials. Results of the assessment of value-average groups where each group consists of 3-4 students. Students as many as 27 people were divided into 8 groups, 5-membered group 3 and 3 group's member 4 people.

Table 1: Average value and Ability Mastery Test Results Examining Student Curriculum and Curriculum Development Course Participants The study curriculum.

\begin{tabular}{|l|l|l|l|l|l|l|}
\hline Group & \multicolumn{2}{l|}{$\begin{array}{l}\text { material } \\
\text { concept }\end{array}$} & \multicolumn{2}{l|}{$\begin{array}{l}\text { The study } \\
\text { material / study }\end{array}$} & \multicolumn{2}{l|}{$\begin{array}{l}\text { material } \\
\text { Preparation }\end{array}$} \\
\cline { 2 - 7 } & Early & After & Early & After & Early & After \\
\hline 01 & 58 & 77 & 66,66 & 80.33 & 69.33 & 81.33 \\
\hline 02 & 56.33 & 78 & 67 & 78.33 & 76 & 79.33 \\
\hline 03 & 54.33 & 79 & 70 & 79.66 & 76 & 78.33 \\
\hline 04 & 52.75 & 79.75 & 67 & 81 & 74.75 & 82.25 \\
\hline 05 & 57.66 & 77.66 & 71.66 & 80.33 & 77.33 & 81.33 \\
\hline 06 & 57.5 & 78 & 71.25 & 80.75 & 74.5 & 79.5 \\
\hline 07 & 60 & 79.75 & 69.5 & 79.25 & 74.75 & 80.5 \\
\hline
\end{tabular}

Based on the implementation of the strategy lectures from the beginning to the end of the course where the lecture material is divided into three groups namely material about the concept of curriculum, review of curriculum and curriculum development unit early childhood education (KTSP 2013 ECD) and stages of each group of material is done differently. But the general strategy that is applied to the eye lectures Lecture Assessing curriculum in early childhood PG Studies Program consists of fieldwork, study the theory and application of theory study results combined with the results of field studies related to document the form of 2013 ECD Curriculum.

Implementation of the strategy lectures on three groups the material turned out to contribute to improve the mastery and skills of students in analyzing, find solutions and at the same time complete the curriculum documents are reviewed units. This is evident from the test results related to student mastery of the three groups of subjects as listed in Table 01 . The control and the ability of students in the development and writing curriculum is reinforced by the end of the course students are required to disseminate and or restore studied early childhood curriculum unit to be imposed curriculum the units of early childhood education, where the student group conducted a study and deal with early childhood unit personnel.

\section{CONCLUSION}

The application of learning strategies courses curriculum study with three groups of materials served to increase mastery, ability and competence of the students in the development of the year 2013 level curriculum for early childhood education. The stages of the strategy of each group study curriculum course materials as follows; stages in mastering curriculum materials that group; (1) examines theories about curriculum with discussion method, (2) field studies, (3) discussion of the results of the field study and compared with theoretical concepts, (4) to draw conclusions about the concept of the curriculum. Group study curriculum materials with the stages; (1) a discussion of the early childhood curriculum structure, (2) examine the shortcomings, accuracy and of the curriculum structure obtained in the unit, (3) determine the form and content of the curriculum structure units of early childhood, (4) designing a full restore. Group 3 materials in the form of early childhood curriculum development unit stages as follows; (1) review the results of the study on the matter two, (2) improvement for each chapter of the curriculum, (3) present and discuss the results of improvements, (4) improvements based on the feedback, (5) the continued improvement to the next chapter until end, (6) presented the results of the overall preparation, (7) pass socialization improving the curriculum in early childhood unit.

\section{REFERENCES}

[1] Amsatul Farida, 2016, Implementasi Lesson Study untuk peningkata kinerja dosen matematika STIMIK 
Duta Bangsa Surakarta; Jurnal Derivat, vol 3 no 2. Desember 2016

[2] Dedi Supardi, 2003, Makna dan Implikasi UndangUndang Sisdiknas, Buletin PADU, Agustus, Jakarta.

[3] Dodge, Diane Trister; Colker Laura J, 1999, The Creative Curriculum for Early Childhood, 3rd edition, Teaching Strategies, Inc, Washington

[4] Djoko Santoso, Sri Waluyanti, 2010,Upaya peningkatan penguasaan konsep dan psikomotorik mata kuliah alat ukur dan pengukuran berbasis lesson study mahasiswa Jurusan Tehnik Elektro FT UNY; Jakarta.

[5] Endah Kuntariyati, 2007, PAUD Menyongsong Kualitas Anak masa depan, Homepage pendidikan Network.

[6] Herry Pujiastuti, et al, 2003, Proses pengindraan dalam proses pembelajaran anak usia dini, Buletin Padu, vol.2 no.01, April 2003, Jakarta.

[7] Harun Rasyid, 2009, Asesmen Perkembangan Anak Usia Dini, Multi Presindo, Jogjakarta.

[8] Jackman, Hilda L, 2012, Early Education Curriculum, A Child's Connection to The World, fifth edition, Printed in the USA.

[9] Masitoh, dkk, 2008, Strategi Pembelajaran TK, Universitas terbuka, Jakarta.

[10] Nyoman Suarta, et al 2006, Sistem penyelenggaraan dan Pembinaan Pelayanan Pendidikan Anak Usia Dini pada Jalur Formal dan Non-formal di Provinsi $N T B$, Laporan penelitian, Mataram, Universitas Mataram

[11] Nyoman Suarta, et al, 2008, Pengembangan kesehatan Ibu dan Anak di Desa pemongkong, laporan kegiatan, Mataram, PKBI NTB.

[12] Yuliani Nurani Sjiono, 2009, Konsep Dasar Pendidikn Anak Usia Dini, PT. Indeks Jakarta.

[13] Saiful Almujut, et al; 2018; penerapan Lesson study melalui metode proyek base learning untuk meningkatkan keaktifan mahasiswa dalam proses pembelajaran di FKIP UNPAS; Jurnal Refleksi Edukatika 8 (2) 2018. 